\title{
The Assessed Usefulness of Management Accounting in Romania and Poland: a Comparative Contingency-Based Study
}

\author{
Alina Almasan ${ }^{1}$, Cristina Circa ${ }^{2}$, Justyna Dobroszek ${ }^{3}$, Ewelina Zarzycka ${ }^{4}$ \\ ${ }^{1,2}$ West University of Timisoara \\ 16 Pestalozzi, 300115, Timisoara, Romania \\ E-mail.alina.almasan@e-uvt.ro, cristina.circa@e-uvt.ro \\ ${ }^{3,4}$ University of Lodz \\ 22/26 Matejki St. 90-237 Lodz, Poland \\ E-mail.justyna.dobroszek@gmail.com,ezarzycka@uni.lodz.pl \\ cross $^{\text {ref }}$ http://dx.doi.org/10.5755/j01.ee.30.3.20483
}

\begin{abstract}
The purpose of this paper is to investigate how selected contingency factors, such as the company profile and the managers' profile, impact on the usefulness of management accounting (MA) in two Eastern European countries: Romania and Poland. In order to achieve the objective of the paper, we employed a questionnaire-based survey addressed to managers of randomly selected companies from various industries. Data were processed by means of several statistical tests, as well as classification and regression trees $(C \& R T)$ and the results were interpreted in the historical context of the two countries. Our investigation showed that management accounting in both countries is oriented towards providing useful information for budgeting and cost control. There is no interest in preparing and communicating information meant to support strategy implementation. It was also found that the information delivered to management is seldom employed in supporting the decision-making process, where its usefulness is rated as relatively low. The most important predictor variable for the assessment of Polish managers is the origin of the company's capital, followed by the education of the managers, while in Romania the assessment is mainly influenced by the managers' function and the origin of capital. The paper contributes to the development of literature in this field by complementing the existing research on MA development in CEE countries, and identifying the internal factors that lead to managers from the two countries perceiving MA usefulness differently.
\end{abstract}

Keywords: Management Accounting Information; Usefulness; Assessment; Comparison; Contingency Factors; Classification and Regression Trees.

\section{Introduction}

The high number of recent changes in accounting have contributed to the distortion of the managers' assessment of the usefulness of accounting information. Although the business environment is in constant flux, the accounting information system, despite being the main source of information, fails to adapt to these changes (Hannon, 2005). The significance of accounting information in decisionmaking is well-known, as accounting is employed by managers as an argument to enhance the credibility of their decisions. Yet, as the gap between the accountants' and managers' perception has grown deeper (Mia \& Chenhall, 1994; Pierce \& O'Dea, 2003; Walker et al., 2011; Grosu et al., 2014), the information delivered by accountants is no longer correlated with the needs of managers.

Numerous comparative studies have been conducted in the field of management accounting (MA). Endenich et al. (2011) prepared a synthesis of such studies, highlighting the heterogeneity of the approaches in terms of both the conceptual framework and the employed research methods. It should be noted that importance was initially placed on developed countries, while developing countries started receiving more attention over time (Endenich, 2011; Kuttner \& Feldbauer-Durstmuller, 2017; Alawattage et al.,
2017). However, we did not find any comparative studies undertaken on two CEE countries with a similar history and economy.

Given the effect of the organizational change on management accounting in Eastern Europe, Atkinson et al. (1997) showed that such changes have had an impact on the collection, processing and use of MA information.

In this context, the paper aims to investigate the impact of several contingency factors (such as company profile and managers' profile) on managers' perception of MA usefulness. Starting with this goal, this research seeks to answer the following research questions: (a) in what kind of activities do managers employ information delivered by management accounting? and (b) is there any interdependency between the manner in which managers assess MA usefulness and certain selected contingency factors?

The choice of Romania and Poland is due to the similar past of these two former communist countries, where the Soviet accounting system was used for more than 50 years. After the fall of communism, the two countries adopted (mainly for cultural and historical reasons) elements of both the German and the AngloSaxon system (Poland), and the French system (Romania), with a different approach towards management accounting. 
Alina Almasan, Cristina Circa, Justyna Dobroszek, Ewelina Zarzycka. The Assessed usefulness of Management ...

The accounting system in Poland, oriented towards integration, facilitated a smoother transition from the Soviet to the current system and emphasized the importance of management accounting. In Romania the adoption of the French accounting system generated a wide gap between financial and management accounting. The differences between these two systems and the different post-communism evolution of the two countries gave us reasons to expect differences in the current perceived usefulness of management accounting. After joining the European Union, both Poland and Romania became attractive for foreign investments, which reshaped the managerial standpoint with regard to this matter.

In order to attain our objective, we performed a comparative analysis of the manner in which managers from Poland and Romania perceive the usefulness of management accounting, as well as of the factors that determine these different perceptions. For this purpose, we employed a questionnaire-based survey addressed to randomly selected companies located in the two said countries. Data were processed by means of several statistical tests and classification and regression trees (C\&RT).

The paper contributes to the development of the literature in this field on more than one level. Firstly, it complements those studies performed in CEE countries which pointed to similar problems with MA (Vamosi, 2000; Haldma \& Laats, 2002; Szychta, 2002; Prochazka, 2010; Albu \& Albu, 2012; Grosu et al., 2014; Gaidiene \& Skyrius, 2006; Szychta, 2018; Zyznarska-Dworczak, 2018). Secondly, it identifies the internal factors that lead to managers from the two countries perceiving MA usefulness differently.

To this purpose, the paper is structured as follows: the second section of the paper provides a brief review of the literature, while the third section describes the research methodology and the data validation. The fourth section outlines the results of the study along with our comments. Some final remarks and conclusions are included in the final section.

\section{Literature Review}

\section{MA Usefulness in Terms of Contingency Factors}

As defined by IMA (2008), "management accounting is a profession that involves partnering in management decision making, devising planning and performance management systems, and providing expertise in financial reporting and control to assist management in the formulation and implementation of an organization's strategy". In Global Management Accounting Principles, published in 2014, CIMA (2014) indicates the broad purposes of management accounting, among others: performance management, cost management, budgeting and planning, decision making, supporting the implementation of strategy, profitability and project management.

MA usefulness has been widely debated in the literature over the recent decades (Hopper, 1980; Burns \& McKinnon, 1992; Mia \& Chenhall, 1994; Gaidiene \& Skyrius, 2006). The topic has been approached either from the standpoint of the MA tools and techniques employed by companies (Scapens, 2006; Pavlatos \& Kostatis, 2015;
Joseph, 2006; Yalcin, 2012; Anderson \& Lanen, 1999; Granlund \& Lukka, 1998; Angelakis et al., 2010; Cheffi \& Beldi, 2012; Szychta, 2018), or based on the contingent factors that influence the design and operations of MA systems (Albu \& Albu, 2012; Haldma \& Laats, 2002; Waweru \& Uliana, 2005; Cadez \& Guilding, 2008; Fisher, 1998; Islam \& Hu 2012; Otley, 2016).

The changes occurring in organizations and their environment have a huge impact on the informational needs of managers, leading to a dynamic increase in the requirements in this area. Therefore, empirical studies examined the informational needs of managers and their level of satisfaction with the information received (Mendoza \& Bescos, 2001; Pierce \& O’Dea, 2003; Burns \& McKinnon, 1992). The perception of managers with regard to MA information is influenced by several factors. The above-mentioned studies point to those factors that are specific to decision-makers; like job function, training and experience (Mendoza \& Bescos, 2001; Burns \& McKinnon, 1993), organisational changes (Atkinson et al., 1999), or even the attitudes dominating in, for instance, CEE countries (Gaidiene \& Skyrius, 2006; Grosu et al., 2014; Haldma \& Laats, 2002; Daniel et al., 2001; Vamosi, 2000).

Defining the set of information that should be provided by management accounting requires the identification of those factors that determine the manner in which information is used and the informational needs of managers. According to the contingency theory, no accounting system is universally appropriate to all organizations in all circumstances (Emmanuel et al., 1990). The features of a system are connected with the circumstances of the organization, while the effectiveness of the accounting system depends on whether it is able to adapt to changes in external and internal factors.

Relevant studies show that it is mainly the environment of the organization, the strategy adopted by the company and the attitudes of the managers that influence the shape of informational systems (e.g. MacIntosh, 1981; Gordon \& Narayanan, 1984; Shank \& Govindarajan, 1989; Fisher, 1998). In a contingency approach, several authors (Gordon \& Miller, 1976; Otley, 2016; Chenhall, 2007; Szychta, 2018) point to the environment (or environmental uncertainty) as one of the most important contingency variables when referring to the design of accounting systems.

The literature points to further contingency factors like the origin of the capital (Albu \& Albu, 2012, Dropulic, 2013), the size of the company (Cadez \& Guilding, 2008; Albu \& Albu, 2012, Haldma \& Laats, 2002, Dropulic, 2013), or the profile of the employees as their experience and education (Duh et al., 2009; Libby \& Luft, 1993), considered to have an equally significant impact on the performance of the MA system as the environment, the technology, the strategy or the organisational culture. Yet, factors related to company features and the manager profile are less frequently explored. Consequently, our study seeks to contribute to the expansion of knowledge in this direction.

The decision to choose factors like company profile and management profile for investigating the interdependency between these and the assessed usefulness of MA in Poland and Romania is based on the results of 
several studies performed in CEE countries, examining the impact of different contingency factors on MA systems. In this context, Albu \& Albu (2012) found that the most important factors related to the existence and use of MA techniques in Romanian entities are the capital type and the company size. More, Haldma \& Laats (2002) point to the size of the organization, as well as to features of emerging economies (the legal accounting environment and the lack of qualified accountants) as main contingency factors. Similarly, the skills of accountants and managers are identified as factors that influence MA practices in less developed countries (Hooper et al., 2009).

\section{The Development of Management Accounting in Poland and Romania}

From the historical perspective of Poland and Romania, it can be observed that management accounting had an earlier origin in Poland, where its development was sparked by the industrial revolution and the first accounting textbooks, published in the 1820s (Szychta, 2015). Due to the hindered economic development, as a result of frequent struggles for independence, the first Romanian handbook of accounting theory relating accounting to the entity's management function dates back to 1901, while "scientific debates" in accounting were held only after 1918 (Albu et al., 2010). It was between the two World Wars when a significant development of management accounting could be seen in both countries (Szychta, 2007, Georgescu \& Cretu, 2011). After 1950, reforms were brought to a standstill by the communist regimes and the Soviet accounting system was "exported" to most of the countries of the former communist bloc (Feleaga, 1996). The centrally planned economy did not allow the design and development of managerial accounting meant to provide useful information for decision-making, though cost accounting played a leading part as it supported the control of economic development.

Polish cost accounting was shaped by the central planning system, the impact of tax authorities, the prevalence of tax rules over accounting rules, as well the centralised management style in enterprises (Szychta, 2002). In the 1980s, Polish enterprises most often used full cost accounting systems, which served as a basis for the preparation of national statistics and the computation of taxes and subsidies (Szychta, 2007). Likewise, Romania had a one-tier accounting system, focused on production, while cost accounting was used to provide a basis for price setting and to compare the performance of different companies (Feleaga, 1996), thereby serving merely to report whether targets were reached or not (Albu et al. 2011).

With the change of the political system in the 1990s, a dynamic development of MA knowledge could be observed in Poland, both in practice and in theory. Multinational companies transferred their solutions to Poland, while Polish academia, already familiar with the relevant practices and theories used in market economies, published textbooks and introduced management accounting into the accounting curricula (see Biadacz, 2011).

After the fall of communism, Romania faced political and legislative instability, high inflation and a poor development of the capital market. Mainly for "political and technical reasons" (Richard, 1995), the Soviet one-tier system was replaced by the French accounting system, with a "brutal" separation between financial and management accounting. Both researchers and practitioners showed little concerns for management accounting. Moreover, confused by accounting regulations, accountants believed that management accounting was optional (Almasan, 2008) and focused entirely on financial accounting.

After EU accession (in 2004 for Poland, in 2007 for Romania), multinational companies established subsidiaries in these two countries and introduced their own MA systems, adding to the levelling out of MA practices.

The evolution of MA, as well as of the context that MA developed in was mostly similar. Hence, we decided to focus on factors related to the profile of a company and the characteristics of the decision-makers.

\section{Research Methodology}

\section{Research Design}

The paper aims to investigate the impact of selected contingency factors like company profile and managers' profile on managers' perception of the usefulness of MA. The study is based on a questionnaire-based survey, conducted by the authors from May 2015 to March 2016.

The questionnaire consists of half-open and closed questions, structured in four different sections: the first two outline a brief characterization of the company and of the respondent, the third section is focused on the design of the MA system within the companies, while the fourth section includes questions meant to capture the managers' assessment of the usefulness of accounting information. The questions are based on earlier research regarding the purpose of information use (Baiman, 1982; Burns \& McKinnon, 1992; Burns \& McKinnon, 1993; Mendoza \& Bescos, 2001). Besides the two national languages, the questionnaire was also available in English.

Prior to its distribution, the questionnaire was pretested in both countries, by interviewing managers of 11 mediumsized and large companies from the two countries (6 companies from Poland and 5 from Romania). The interviews were intended to eliminate any ambiguous wordings from the questionnaire and clarify the terminology used therein. The questions were then adjusted in line with the feedback received during the interviews. The questionnaire was distributed to the best-known consultancy firms from the two countries, who then forwarded it to their clients. Out of 154 responses, 116 originated from Poland and 38 from Romania. One questionnaire corresponded to one respondent participating in the study.

Data were processed using descriptive statistics and selected statistical tests. Based on the t-test for two means and the Mann-Whitney U test, we examined whether the purpose for which MA information is used differs significantly in the population of managers in Romania and Poland. For the purpose of determining the contingent factors related to the differences in the assessed usefulness of MA information, classification and regression trees (C\&RT) were used. Statistica 13.3 was used for this purpose. 
Alina Almasan, Cristina Circa, Justyna Dobroszek, Ewelina Zarzycka. The Assessed usefulness of Management ...

C\&RT is a recursive partitioning method that builds classification and regression trees for predicting continuous dependent variables (regression) and categorical predictor variables (classification). This technique is particularly useful for data mining tasks and reveals relationships between variables that could pass unnoticed by other traditional analytical tools (see Breiman et al., 1984; Ripley, 1996).

\section{Sample Profile}

The study covers companies from various industries different in terms of number of employees, turnover and origin of the capital - operating in Poland and Romania. Both in Poland and in Romania the survey includes mainly manufacturing companies (52\%, $61 \%$ respectively), while about $30 \%$ of the companies from both Poland and Romania are service providers, with slightly over $10 \%$ being trade companies.

Over $60 \%$ of the surveyed companies from both Poland and Romania can be classified as large in terms of their number of employees. From the standpoint of their turnover the companies included in the survey show a different profile: $50 \%$ of the Polish, but only $18 \%$ of the Romanian responding companies disclose a turnover of over EUR 200 million. Most Polish and Romanian companies included in the survey have foreign capital $(42 \%, 57 \%$ respectively of the study population).

The structure of the respondents in respect of their education should be highlighted. $98 \%$ of the Polish managers hold a Master's degree, $40 \%$ have completed an
MBA and $9 \%$ hold a Ph.D., while $68 \%$ of the Romanian managers hold a Master's degree and only $13 \%$ have an MBA degree. The surveyed managers come both from operations departments like production, logistics, purchasing or sales $(53 \%$ of the Romanian and $50 \%$ of the Polish managers) and from support departments like HR, IT or finance (41\% of the Romanian and $39 \%$ of the Polish managers). In both countries, the best-represented experience classes are 6 to 10 years, followed by 1 to 5 years.

\section{Results and Discussions}

\section{The Purpose of Using MA Information}

One of the main concerns of the study regards the extent to which managers actually employ the information provided by the MA system in performing management tasks. In this context, we started from the roles that IMA (2008) and CIMA (2014) assign to MA: performance management, cost management, budgeting and planning, decision making, supporting the implementation of strategy, profitability and project management. In addition, we considered the results of several studies showing the traditional role of MA (Haldma \& Laats, 2002; Pierce \& O’Dea, 2003; Albu \& Albu, 2012; Yalcin, 2012; Grosu et al., 2014; Szychta, 2018).

We used a Likert scale (1 - never, 2 - rarely, 3 occasionally, 4 - often, 5 - very often), which led us to the results presented in Table 1 .

Table 1

The Purpose of Using MA Information

\begin{tabular}{|c|c|c|c|c|}
\hline \multirow[b]{2}{*}{ Purposes } & \multicolumn{2}{|c|}{ ROM } & \multicolumn{2}{|c|}{ POL } \\
\hline & Average & $\begin{array}{l}\text { Standard } \\
\text { Deviation }\end{array}$ & Average & $\begin{array}{l}\text { Standard } \\
\text { Deviation }\end{array}$ \\
\hline Preparing budgets & 4.588 & 0.743 & 4.152 & 1.128 \\
\hline Performance measurement & 4.412 & 0.743 & 3.696 & 1.324 \\
\hline Cost control & 4.382 & 0.697 & 4.283 & 0.906 \\
\hline Cost reduction & 4.088 & 0.900 & 3.783 & 1.003 \\
\hline Long term planning & 3.912 & 0.965 & 3.413 & 1.268 \\
\hline Increasing profitability & 3.794 & 0.914 & 3.217 & 1.405 \\
\hline Implementing the strategy & 3.647 & 0.691 & 3.065 & 1.299 \\
\hline Managing own department & 3.647 & 1.069 & 3.065 & 1.299 \\
\hline Assessing internal projects & 3.412 & 1.047 & 3.130 & 1.384 \\
\hline Making investment decisions & 3.324 & 1.147 & 2.739 & 1.518 \\
\hline Make or buy / outsourcing decision-making & 3.029 & 1.218 & 2.304 & 1.324 \\
\hline Making decisions regarding $\mathrm{R} \& \mathrm{D}$ & 2.765 & 1.182 & 2.196 & 1.303 \\
\hline
\end{tabular}

Romanian managers appraise the information provided by the MA system as most useful for the preparation of budgets (average rating of 4.588), the measurement and evaluation of performance (4.412), cost control and cost reduction (respectively 4.382 and 4.088), and long-term planning (3.912). Polish managers consider MA information as extremely useful for cost control (4.283), budgeting (4.152), cost reduction (3.783), performance measurement and evaluation (3.696) and long-term planning (3.413).

The results in this matter are similar in the two countries and it should be noted that the first four positions are the traditional areas of management accounting, i.e. budgeting, performance measurement and evaluation and cost control. Such facts may indicate the dominance of the traditional MA techniques and tools that mainly support the operational management processes (e.g. operational planning and operational control) in the surveyed companies. However, the authors are puzzled by the low assessment of MA information in supporting the decision-making process, both in the short and long term, the management of departments or the implementation of strategies. These results confirm the conclusions of Hall (2010), who found that managers use accounting information more to become acquainted with their work environment than for decision-making. When considering the purposes of using specific MA information as identified by IMA (2008) and CIMA (2014), managers in Poland and Romania employ the information produced by MA for problem-solving and control. These findings contrast with the frequently encountered opinion that information is mainly useful and valuable in the context of 
decision making (among others: Baiman, 1982; Chenhall \& Morris, 1986). Yet, they are in line with the results of Burns \& McKinnon (1992; 1993), showing that managers who need to make decisions search for other sources of information.

It can be noticed however that Polish managers rate the usefulness of MA tools slightly lower than their
Romanian colleagues. The t-test for 2 means has been used to examine whether the assessment of the extent to which the information provided by the MA system is employed for the identified management tasks differs significantly in the populations of Polish and Romanian managers.

Table 2 discloses the p-values for the compared populations and the identified tasks.

Table 2

Results of p-Values for Compared Populations and Identified Tasks

\begin{tabular}{|l|c|c|}
\hline \multicolumn{1}{|c|}{ Purposes } & \multicolumn{2}{c}{ ROM vs POL } \\
\cline { 2 - 3 } & \multicolumn{1}{c|}{ Test statistic: t(124) } & Two-tailed test p \\
\hline Preparing budgets & 2.08922 & 0.03873 \\
\hline Performance measurement & $\mathbf{2 . 9 8 0 4 4}$ & $\mathbf{0 . 0 0 3 4 6 5}$ \\
\hline Cost control & 0.581149 & 0.5622 \\
\hline Cost reduction & 1.55847 & 0.1217 \\
\hline Long term planning & 2.07961 & 0.03962 \\
\hline Increasing profitability & 2.22291 & 0.02803 \\
\hline Implementing the strategy & 2.48051 & 0.01446 \\
\hline Managing own department & 2.33358 & 0.02123 \\
\hline Assessing internal projects & 1.07541 & 0.2843 \\
\hline Making investment decision & 2.03776 \\
\hline Make or buy/outsourcing decision making & $\mathbf{2 . 7 8 6 3 5}$ & 0.0437 \\
\hline Making decisions regarding R\&D & 2.22921 & $\mathbf{0 . 0 0 6 1 6 9}$ \\
\hline
\end{tabular}

*values indicating the differences are bolded

Assuming a significance level of $1 \%$, there is an important difference between Polish and Romanian managers with regard to the mean rating of using information provided by the MA system for performance measurement, i.e. taking make or buy decisions. In this context, Romanian managers rate the use of management information in these areas much higher than Polish managers.

Responses of Polish and Romanian managers were further compared based on the Mann-Whitney U test. The following table (Table 3 ) contains a set of $\mathrm{Z}$ statistics, and p-values for compared populations and identified tasks.

Table 3

Results of p-Values for Compared Populations and Identified Tasks

\begin{tabular}{|c|c|c|}
\hline \multirow{2}{*}{ Purposes } & \multicolumn{2}{|c|}{ ROM vs POL } \\
\hline & Z-Score & p-value \\
\hline Preparing budgets & -1.8055 & 0.03515 \\
\hline Performance measurement & -2.6134 & 0.00453 \\
\hline Cost control & -0.1731 & 0.43251 \\
\hline Cost reduction & -1.4482 & 0.07353 \\
\hline Long term planning & -1.8384 & 0.03288 \\
\hline Increasing profitability & -1.8934 & 0.02938 \\
\hline Implementing the strategy & -2.0253 & 0.02118 \\
\hline Managing own department & -2.3221 & 0.01017 \\
\hline Assessing internal projects & -0.8546 & 0.19766 \\
\hline Making investment decision & -1.9099 & 0.02807 \\
\hline Make or buy/outsourcing decision making & -2.7838 & 0.00272 \\
\hline Making decisions regarding R\&D & -2.4045 & 0.0164 \\
\hline
\end{tabular}

*values indicating the differences are bolded

Similarly to the t-test, the Mann-Whitney U test shows a $99 \%$ probability that the usefulness ratings of the information provided by the MA department for performance measurement and taking make or buy decisions differ significantly between Polish and Romanian managers $(\mathrm{p}<0.01)$. Polish managers consider this information to be less useful for the specified tasks than their counterparts from Romania (average/total responses of Polish managers is lower than that of Romanian managers).

\section{The Contingent Factors Determining Differences in the} Assessment of MA Usefulness

The conducted empirical study on the purpose to which MA information is used revealed a major similarity of responses and evaluations among Polish and Romanian managers. In order to determine the contingent factors related to the differences in the assessment of MA information usefulness, we used classification and regression trees (C\&RT). We examined the interdependence between the assessment of Polish and Romanian managers (dependent variable) and the following predictor variables:

1. the company profile:

- type of company (predictor type: manufacturer, service),

- $\quad$ size (predictor size: big, medium small),

- $\quad$ origin of capital (predictor capital: $100 \%$ foreign, $100 \%$ domestic, mixed), 
Alina Almasan, Cristina Circa, Justyna Dobroszek, Ewelina Zarzycka. The Assessed usefulness of Management ...

2. manager profile:

- professional experience (predictor experience: short (0-5 years), average (6-10 years), long (11more years)),

- education (predictor education: bachelor \& master's, master's \& postgraduate studies)
- managers' function (Executive, Production \& Logistic \& Procurement, Finance \& IT \& HR, Sales \& Marketing).

The dependent variable was measured on a Likert scale from 1-5 (where 5 - very high, 4 - high, 3 - neutral, 2 - low, 1 - very low). The tree graph for the classification tree for the assessment of MA usefulness by Polish managers is shown in Figure 1:

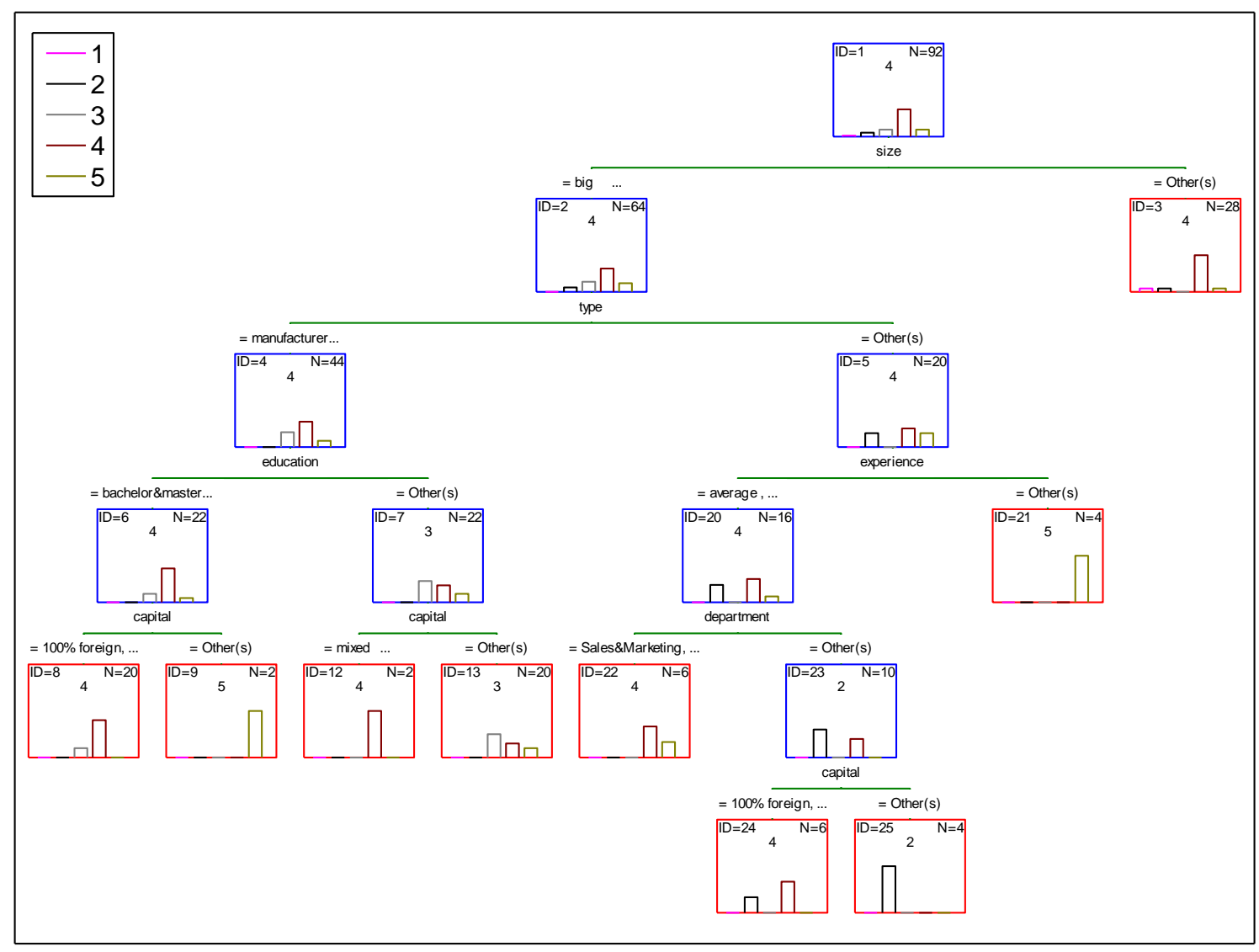

Figure 1. Tree for the Assessment of MA Information Usefulness by Polish Managers

The classification tree has 9 terminal nodes. In the graph, terminal nodes are outlined with red lines, while the remaining split nodes are outlined with blue lines. The tree graph shows that managers with average experience, from departments other than Sales \& Marketing, in large service companies with foreign capital (node ID=24) consider the MA usefulness high (score 4). Surprisingly, managers from similar companies, but with domestic and mixed capital, rate the usefulness much lower (node ID=24 and score 2). Moreover, managers with postgraduate studies working in domestic and foreign manufacturing companies are more critical in their assessment (node ID=13 and score 3) than their counterparts in enterprises with mixed capital (node
$\mathrm{ID}=12$ and score 4). Finally, the assessment of managers without postgraduate studies working in foreign, large, manufacturing companies is lower (ID=8 and score 4) than in the case of professionals from enterprises with local and mixed capital (node ID=9, score 5).

When univariate splits are performed, the predictor variables can be ranked on a 0 - 100 scale in terms of their potential importance in accounting for responses on the dependent variable. For the assessment of Polish managers, the origin of the capital (capital), as well as the education and experience of the manager (education and experience) are clearly very important, while the size of the company (size) is relatively unimportant (see Figure 2). 


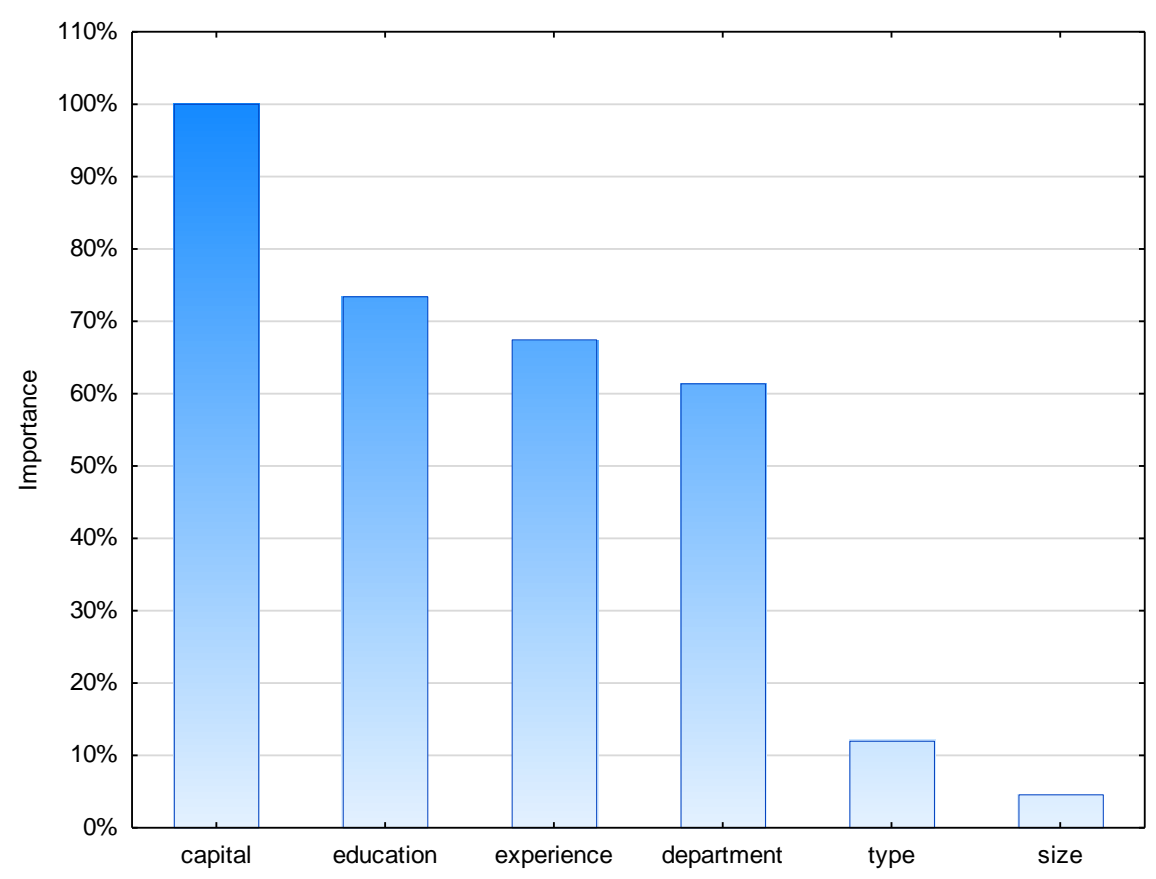

Figure 2. The Importance of the Predictor Variables for the Assessment by Polish Managers

Similar analyses were conducted for Romanian managers. The tree graph for the classification tree for the assessment of MA usefulness by Romanian managers is shown in Figure 3.

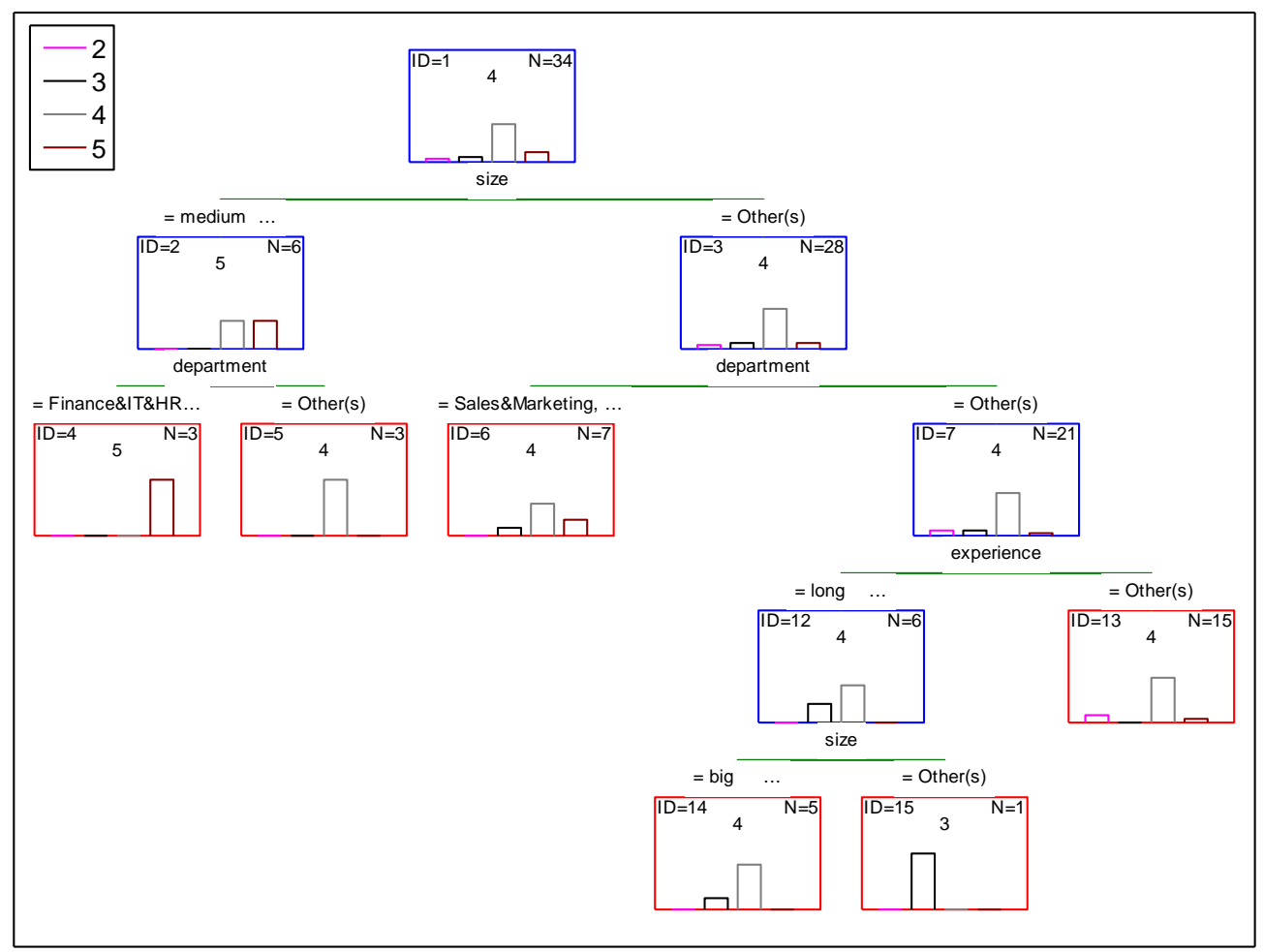

Figure 3. Tree for the Assessment of MA Information Usefulness by Romanian Managers

The classification tree has 6 terminal nodes. The tree graph shows that Romanian managers from supporting departments (Finance \& IT \& HR), working in mediumsized companies (node ID $=4$ ), assessed MA usefulness in their work as very high (score 5), while managers of other surveyed departments from companies of a similar size (node ID=5) rated MA usefulness slightly lower (score 4). The high ratings are not a surprise as MA information is of particular importance to those dealing with finances. Moreover, it is telling that the usefulness has been rated highly (score 4) by managers from large enterprises with long experience, working in all examined departments, except for marketing and sales (node ID=14). This group of managers understands the importance of management accounting due to their longer experience and the larger scale of the operations of their enterprises, which requires 
Alina Almasan, Cristina Circa, Justyna Dobroszek, Ewelina Zarzycka. The Assessed usefulness of Management ...

precise data. The most critical approach in terms of MA assessment belongs to managers with long experience from small and medium companies working in departments other than Sales \& Marketing (node ID=15, score 3), whereas their counterparts from large companies rate management accounting higher (node $\mathrm{ID}=14$, score 4). This difference in satisfaction between managers from small/medium and large companies may be down to the lack of more advanced MA techniques in smaller companies. As for Romanian managers, the area of expertise (department), the origin of the capital (capital) and the company size (size) are very important, while the company type (type) is relatively unimportant (see Figure 4).

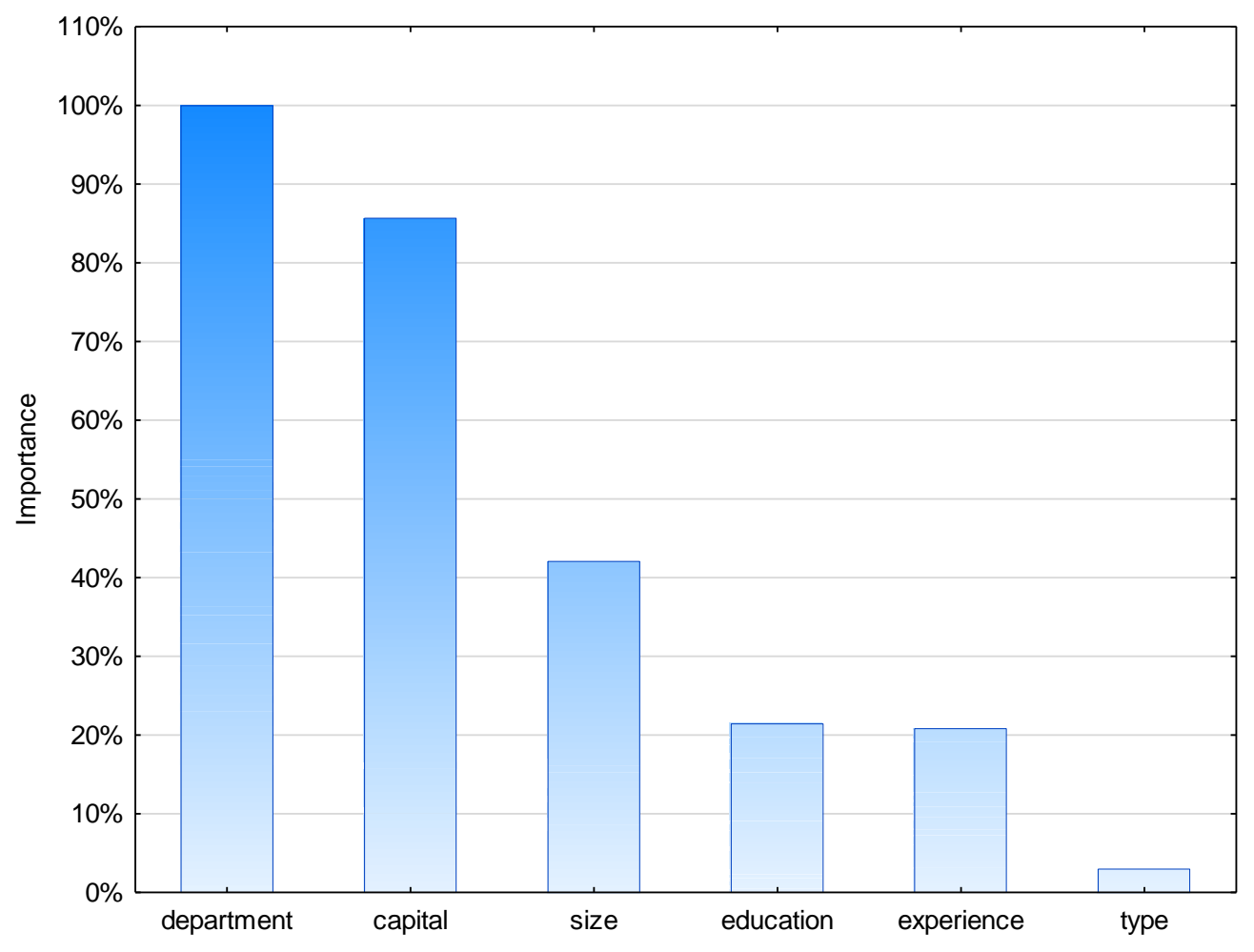

Figure 4. The Importance of the Predictor Variables for the Assessment of Romanian Managers

\section{Conclusions}

The paper aims to provide a comparative study of managers' assessment of the usefulness of MA information in two countries located in the Central and Eastern Europe, i.e. Romania and Poland, considering several contingency factors. The research relied on a questionnaire-based survey and set the investigation in a historical context, debating its impact on the development of management accounting.

The research results reveal a similar purpose when using MA information by the managers in the two countries. Managers have a short-term view, oriented towards reaching efficiency objectives. In support of the above, our investigation showed that, in both countries, management accounting uses rather traditional tools, providing adequate information for budgeting, performance measurement and cost control. These results corroborate the conclusions of prior studies on the weak use of MA information in decision-making (Hall, 2010; Grosu et al., 2014; Szychta, 2018).

The research of Baiman (1982), Chapman et al. (2009) and, most importantly, of Mia (2002) show that increased uncertainty in the business environment leads to the more frequent use of information derived from the MA system by managers, which improves their efficiency. Contrariwise, in the two countries considered in our analysis, the information delivered to management is seldom employed in supporting the decision-making process, where its usefulness is rated as relatively low.

From a historical perspective, it can be observed that the two countries evolved at a different pace: while Poland has shown an increased concern for cost and management accounting since the $80 \mathrm{~s}$, the changes in Romanian accounting from the early 90s slowed down the development of this field. Yet, the communist historical background of the two countries left a related imprint on the accounting system and, more specific, on management accounting.

The conclusions of our study can be organized around the two main factors - company profile and managers' profile:

With regard to the company profile, we observe that the type of company has a weak influence on managers' perception, both in Poland, and in Romania.

Company size appears to be more important to Romanian managers, confirming the conclusions of Albu \& Albu (2012), Haldma \& Laats (2002) and Chenhall (2007). Managers from large and medium companies assess MA higher than their counterparts in small enterprises, where MA techniques are undeveloped. This can be explained by the fact that managers from large and medium companies face more complex problems than managers from small companies, and their need for MA 
information is stronger. Hence, they are more aware of the importance/usefulness of management accounting to their activity.

The origin of capital is the most important predictor variable in Poland and a significant one in Romania, in line with other studies (Anderson \& Lanen, 1999; Albu \& Albu, 2012; Drupulic, 2013; Duh et al., 2009). Companies with foreign capital operating in Poland and Romania are usually multinationals that implement their own MA systems locally. As a result, the assessment of these systems is high, although managers have limited autonomy in these businesses, as the strategical decisions are made at headquarters, limiting the usefulness of some strategic tools of management accounting. This is a further explanation of the findings from the first part of the research, which showed that MA in both countries uses traditional tools more, providing adequate information for budgeting, performance measurement and cost control. Moreover, in domestic companies, or companies with mixed capital, the assessments are lower and, in the case of Poland, even very low. This is due to historical reasons, as management accounting in such companies is still undeveloped. Changing the economic context after the fall of communism led local companies to adjust their MA systems. Nevertheless, these companies did not manage to develop and appropriately implement MA techniques and instruments that were able to support decision-making. This conclusion corroborates the results of prior studies from CEE countries (Gaidiene \& Skyrius, 2006; Yalcin, 2012; Albu \& Albu 2012; Grosu et al., 2014; Szychta, 2018).

As for the managers' profile, education and experience appear to be factors with a significant influence in Poland, while in the case of Romania the influence of these variables is weaker. Similarly, Hooper et al. (2009) and Libby \& Luft (1993) emphasize the importance of managers' education and experience in using the MA system. This difference between countries results from the disproportion in the education background of the researched managers, as well as from the shorter period of MA development in Romania. Polish managers with longer experience and better education background, i.e. managers with postgraduate studies ( $\mathrm{PhD}, \mathrm{MBA})$, are more critical towards management accounting.

The managers' function is the most important factor for the assessment of Romanian managers. Especially managers from supporting departments (Finance, IT, HR) rate MA usefulness very highly. The assessment of other departments is slightly lower, obviously because the finance department better understands the importance of MA information. In Poland, this factor is of lower importance.

In this context, the present paper contributes from a theoretical perspective to the development of the literature by complementing the existing research on MA development in CEE countries (see among others: Vamosi, 2000; Haldma \& Laats, 2002; Szychta, 2002; Prochazka, 2010; Albu \& Albu, 2012; Grosu et al., 2014; Gaidiene \& Skyrius, 2006; Szychta, 2018; Zyznarska-Dworczak, 2018). Moreover, it provides a comparative analysis of MA usefulness for managers, through the lens of contingency factors that lead to different perceptions of its value, and broadens knowledge on contingency theory (see: Gordon \& Miller, 1976; Otley, 2016; Chenhall, 2007; Szychta, 2018) and comparative analyses (Endenich, 2011; Kuttner \& Feldbauer-Durstmuller, 2017). From the practical perspective, the results of our study draw attention to the internal factors that exert the strongest influence on the perceived usefulness of management accounting. Thus, the findings can serve as a guide for managers to shape and improve their MA system in order to increase the usefulness of MA information for managing a company.

The results were interpreted in the historical context of the two countries, as the background of Poland and Romania was the starting point of the current situation. This historical background influences MA use in both countries, although the differences are not as significant as expected. These expectations were based on the different evolution of management accounting in the two countries after the fall of communism, i.e. a much more dynamic evolution in Poland than in Romania.

As to the limits of the research, we should point to the small number of responses we relied on, which does not allow us to universalize our conclusions. Secondly, we analysed only a limited number of contingent factors, as the use of more factors would have made the research impossible to carry out from a methodological point of view (Malmi, 1997; Chenhall, 2007). Based on the above, as future research directions, we suggest analysing the impact of other contingent factors on the way in which managers assess MA usefulness.

\section{References}

Alawattage, C., Wickramasinghe, D., Tsamenyi, M., \& Uddin, S. (2017). Doing critical management accounting research in emerging economies. Advances in Scientific and Applied Accounting, 10(2), 177-188. http://dx.doi.org/10.14392/ asaa.2017100203

Albu, C. N., Albu, N., Faff, R., \& Hodgson, A. (2011). Accounting competencies and the changing role of accountants in emerging economies: The case of Romania. Accounting in Europe, 8(2), 153-182. https://doi.org/10.1080/1744 9480.2011 .621395

Albu, N., Albu, C. N., Girbina M. M., \& Sandu I. M. (2010). The Institutional Framework of the Romanian Accounting Profession - An Exploratory Study. Proceedings of the 5th WSEAS International Conference on Economy and Management Transformation, II, 677-681. Available on the internet: http://www.wseas.us/e-library/conferences/ 2010/Timisoara W/EMT/EMT2-41.pdf 
Alina Almasan, Cristina Circa, Justyna Dobroszek, Ewelina Zarzycka. The Assessed usefulness of Management ...

Almasan, A. (2008). Challenges of a dynamic and complex environment on management accounting. The Annals of the University of Oradea. Economic Sciences, XVII(3), 913-917. Available on the internet: http://steconomiceuoradea.ro/ anale/volume/2008/v3-finances-banks-accountancy/168.pdf

Anderson, S. W., \& Lanen W. N. (1999). Economic transition, strategy and the evolution of management accounting practices: the case of India. Accounting, Organizations and Society, 24, 379-412. https://doi.org/10.1016/S0361-3682(97)00060-3

Angelakis, G., Theriou, N., \& Floropoulos, I. (2010). Adoption and benefits of management accounting practices: Evidence from Greece and Finland. Advances in Accounting, 26(1), 87-96. https://doi.org/10.1016/j.adiac.2010.02.003

Atkinson, A. A., Balakrishnan, R., Booth, P, Cote, J. M., Groot, T., Malmi, T., Roberts, H., Uliana, E., \& Wu, A. (1997). New directions in management accounting research. Journal of Management Accounting Research, 9, 79-108. https://doi.org/10.1016/S1044-5005(90)70051-0

Baiman, S. (1982). Agency Research in Managerial Accounting: A Survey. Journal of Accounting Literature, 1, $154-213$.

Biadacz, R. (2011). Rachunkowosc zarzadcza w Polsce po roku 1990 (Management Accounting in Poland after 1990). Prace Naukowe UE we Wroclawiu, 181, 24-33.

Breiman, L., Friedman, J. H., Olshen, R. A., \& Stone, C. J. (1984). Classification and regression trees. Monterey. CA: Wadsworth \& Brooks/Cole Advanced Books \& Software.

Burns, W. J., \& McKinnon, S. M. (1992). Management information and accounting information: what do managers want? In Epstein, M.J. (ed.) Advances in Management Accounting (pp. 55-80). Greenwich: Jail Press Inc., vol. 1.

Burns, W. J., \& McKinnon, S. M. (1993). Information and managers: a field study. Journal of Management Accounting Research, 5, 84-108.

Cadez, S., \& Guilding, C. (2008). An exploratory investigation of an integrated contingency model of strategic management accounting. Accounting, Organizations and Society, 33(7/8), 836-863. https://doi.org/10.1016/j.aos.2008.01.003

Chapman, C. S., Hopwood, A. G., \& Shields, M. D. (2009). Handbook of Management Accounting Research, Oxford: Elsevier.

Chartered Institute of Management Accountants (2014). Global Management Accounting Principles: Improving decisions and building successful organisations. Available on the internet: https://www.cgma.org/content/dam/cgma/resources/reports/ downloadabledocuments/global-management-accounting-principles.pdf

Cheffi, W., \& Beldi, A. (2012). Analysis of managers' use of management accounting. International Journal of Business, 17(2), $113-125$.

Chenhall, R., \& Morris, D. (1986). The impact of structure, environment, and interdependence on the perceived usefulness of management accounting systems. The Accounting Review, 61(1), 16-35. Available on the internet: http://www.jstor. org/stable/247520

Chenhall, R. H. (2007). Theorizing contingencies in management control systems research. In Chapman, C.S., Hopwood, A.G. \& Shields, M.D. (Eds.), Handbook of Management Accounting Research (163-205), Elsevier. https://doi.org/10.10 16/S1751-3243(06)01006-6

Daniel, P., Suranova, Z., \& De Beelde, I. (2001). The development of accounting in Slovakia. The European Accounting Review, 10, 2, 343-359. https://doi.org/10.1080/09638180126639

Dropulic, I. (2013). The effect of contingency factors on management control systems: a study of manufacturing companies in Croatia. Economic Research, 26(1), 369-382. https://doi.org/10.1080/1331677X.2013.11517657

Duh, R. R., Xiao, J. Z., \& Chow, C. W. (2009). Chinese firms' use of management accounting and controls: facilitators, impediments, and performance effects. Journal of International Accounting Research, 8, 1-30. https://doi.org/10.23 08/jiar.2009.8.1.1

Emmanuel, C., Otley, D., \& Merchant, K. (1990). Accounting for Management Control, 2nd edition. London: Chapman \& Hall. https://doi.org/10.1007/978-1-4899-6952-1

Feleaga, N. (1996). Controverse contabile. Dificultati conceptuale si credibilitatea contabilitatii (Accounting controversies: Conceptual difficulties and the credibility of accounting), Bucharest: Economica.

Fisher, J. (1998). Contingency theory, management control systems and firm outcomes: past results and future directions. Behavioral Research in Accounting, 10(Supplement), 47-64.

Gaidiene, Z., \& Skyrius, R. (2006). The usefulness of management accounting information: users' attitudes. Ekonomika, 74, 21-37. Available on the internet: http://jackson.com.np/documents/MBA4/Management_accounting/the-usefulness-ofmanagement-accounting-information-users-attitudes.pdf 
Georgescu, I., \& Cretu, L. (2011). Management accounting in higher education in Romania. In Innovation and Knowledge Management: A Global Competitive Advantage - Proceedings of the 16th International Business Information Management Association Conference (IBIMA), 1987-1995. Available on the internet: http://www.bursedoctorale.ro/ public/ documente/articole/1330171611_paper\%20197.pdf

Gordon, L. A., \& Miller, D. A. (1976). Contingency framework for the design of accounting information systems. Accounting, Organizations and Society, 1(1), 56-69. https://doi.org/10.1016/0361-3682(76)90007-6

Gordon, L. A., \& Narayanan, V. K. (1984). Management accounting systems, perceived environmental uncertainty and organizational structure: an empirical investigation. Accounting, Organizations and Society, 9(1), 33-47. https://doi.org/10.1016/0361-3682(84)90028-X

Granlund, M., \& Lukka, K. (1998). It's a small world of management accounting practices. Journal of Management Accounting Research, 10(1), 153-179.

Grosu, C., Almasan, A., \& Circa, C. (2014). The current status of management accounting in Romania: the accountants' perspective. Journal of Accounting and Management Information Systems, 13(3), 537-558. Available on the internet: http://cig.ase.ro/jcig/art/13_3_6.pdf

Haldma, T., \& Laats, K. (2002). Contingencies influencing the management accounting practices of Estonian manufacturing companies. Management Accounting Research, 13(4), 379-400. https://doi.org/10.1006/mare.2002.0197

Hall, M. (2010). Accounting information and managerial work. Accounting, Organizations and Society, 35(3), 301-315. https://doi.org/10.1016/j.aos.2009.09.003

Hannon, N. J. (2005). The cost accountant is dead; long live the business process analyst. Strategic Finance, 87(6), 59-60. Available on the internet: http://sfmagazine.com/wp-content/uploads/sfarchive/2005/12/XBRL-The-cost-accountant-isdead-long-live-the-business-process-analyst.pdf

Hopper, T., Tsamenyi, M., Uddin, S., \& Wickramasinghe D. (2009). Management accounting in less developed countries: what is known and needs knowing. Accounting, Auditing and Accountability Journal, 22, 469-514. https://doi.org/10.1108/ 09513570910945697

Hopper, T. M. (1980). Role conflicts of management accountants and their position within organization structures. Accounting, Organizations and Society, 5(4), 401-411. https://doi.org/10.1016/0361-3682(80)90039-2

Institute of Management Accountants. (2008). Statements on Management Accounting - Definition of Management Accounting. Available on the internet: www.imanet.org//-/media/6c984e4d7c854c2fb40b96bfbe991884.ashx?as $=1 \& \mathrm{mh}=$ 200\&mw=200\&hash=4E6AF697C021AA3 EB0C358AE6FE2AEB1BCA992DE

Islam, J., \& Hu, H. (2012). A literature review on contingency theory in managerial accounting. African Journal of Business Management, 6(15), 5159-5164. Available on the internet: http://www.academicjournals.org/article/article1 380711715 Islam\%20and\%20Hu.pdf https://doi.org/10.5897/AJBM11.2764

Joseph, G. (2006). Understanding Management Accounting Techniques in the Context of Organizational Change. Management Accounting Quarterly, 7(4), 24-32.

Kuttner, M., \& Feldbauer-Durstmuller, B. (2017). Comparative management accounting in developing countries: state-of-theart and future perspectives. International Journal of Business Research, 16(3), 81-104. https://doi.org/10.18374/IJBR-163.6

Libby, R., \& Luft, I. (1993). Determinants of judgment performance in accounting settings: Ability, knowledge, motivation, and environment. Accounting, Organizations and Society, 18(5), 425-450. https://doi.org/10.1016/0361-3682(93)90040-D

MacIntosh, N. B. (1981). A contextual model for information systems. Accounting, Organizations and Society, 6(1), 39-52. https://doi.org/10.1016/0361-3682(81)90021-0

Malmi, T. (1997). Towards explaining activity-based costing failure: accounting and control in a decentralized organization, Management accounting research, 8(4), 459-480. https://doi.org/10.1006/mare.1997.0057

Mendoza, C., \& Bescos, P. L. (2001). An explanatory model of managers' information needs: implications for management accounting. The European Accounting Review, 10(2), 257-289. https://doi.org/10.1080/713764598

Mia, L. (2002). The Role of MAS Information in Organizations: An Empirical Study. The British Accounting Review, 25(3), 269-285. https://doi.org/10.1006/bare.1993.1026

Mia, L., \& Chenhall, R. (1994). The usefulness of management accounting systems, functional differentiation and managerial effectiveness. Accounting, Organizations and Society, 19(1), 1-13. https://doi.org/10.1016/0361-3682(94)90010-8 
Alina Almasan, Cristina Circa, Justyna Dobroszek, Ewelina Zarzycka. The Assessed usefulness of Management ...

Otley, D. T. (2016). The contingency theory of management accounting and control: 1980-2014. Management Accounting Research, 31, 45-62. https://doi.org/10.1016/j.mar.2016.02.001

Pavlatos, O., \& Kostakis, H. (2015). Management accounting practices before and during economic crisis: Evidence from Greece. Advances in Accounting, 31(1), 150-164. https://doi.org/10.1016/j.adiac.2015.03.016

Pierce, B., \& O'Dea, T. (2003). Management accounting information and the needs of managers. Perceptions of managers and accountants compared. British Accounting Review, 35(3), 257-290. https://doi.org/10.1016/S0890-8389(03)00029-5

Prochazka, D. (2010). The development of financial and management accounting after the IFRS adoption: a case from the Czech Republic. Available on the internet: http://ssrn.com/abstract=1660122.

Richard, J. (1995). The evolution of accounting chart models in Europe from 1900 to 1945. European Accounting Review, 4(1), 87-124. https://doi.org/10.1080/09638189500000004

Ripley, B. D. (1996). Pattern recognition and neural networks. Cambridge: Cambridge University Press. https://doi.org/10.101 7/ CBO9780511812651

Scapens, R. W. (2006). Understanding management accounting practices: A personal journey. The British Accounting Review, 38(1), 1-30. https://doi.org/10.1016/j.bar.2005.10.002

Shank, J. K., \& Govindarajan, V. (1989). Strategic Cost Analysis, the Evolution from Managerial to Strategic Accounting. Chicago: Irwin.

Szychta, A. (2002). The scope of application of management accounting methods in Polish enterprises. Management Accounting Research, 13(4), 401-418. https://doi.org/10.1006/mare.2002.0198

Szychta, A. (2007). Etapy ewolucji i kierunki integracji metod rachunkowosci zarzadczej (Evolution and integration of methods of management accounting). Wydawnictwo UL, Lodz.

Szychta, A. (2015). 19th century factory accounting in the light of Polish accounting manuals. Paper presented on EAA 38th Annual Congress, 28-30 April, Glasgow.

Szychta, A. (2018). Management accounting practices in developing countries since the 1990s: the case of Poland. Zeszyty Teoretyczne Rachunkowosci Stowarzyszenie Księgowych, 99(155), 119-148. https://doi.org/10.5604/01.3001.0012.2936

Vamosi, T. (2000). Continuity and change; management accounting during processes of transition. Management Accounting Research, 11(1), 27-63. https://doi.org/10.1006/mare.1999.0122

Walker, K. B., Fleischman, G. M., \& Johnson, E. N. (2011). Perceptions of management accounting services. Global Journal of Business Research, 5(1), 111-123. Available on the internet: https://papers.ssrn.com/sol3/papers.cfm?abstract_id $=1873514$

Waweru, N. M., \& Uliana, E. (2005). Predictors of management accounting change in South Africa: Evidence from five retail companies. South African Journal of Accounting Research, 19(1), 37-71. https://doi.org/10.1080/1029 1954.2005. 11435118

Yalcin, S. (2012). Adoption and Benefits of Management Accounting Practices: An Inter-country Comparison. Accounting in Europe, 9(1), 95-110. https://doi.org/10.1080/17449480.2012.664394

Zyznarska-Dworczak, B. (2018). The Development Perspectives of Sustainable Management Accounting in Central and Eastern European Countries. Sustainability, 10 (5), 1-21. https://doi.org/10.3390/su10051445

The article has been reviewed.

Received in April 2018; accepted in June 2019. 